\title{
Models of Analyzing the Influence of Factors on Profit Rate Formation
}

\author{
Article history: \\ Received: 26 September 2013 \\ Sent for revision: 21 October 2013 \\ Received in revised form: 3 November 2013 \\ Accepted: 7 November 2013 \\ Available online: 28 March 2014
}

\begin{abstract}
The analysis in this paper is focused on identifying the impact of individual factors on profit rate's elements. The primary aim of this paper is to overview methodological solutions for understanding the full content of profit rate as a determinant of economic quality as well as a final indicator of reproduction results. The model of analysing profit rate factors was applied in a Serbian enterprise that manufactures construction materials from baked clay. The application is aimed at testing the range in determining elements and factors of economic success of the enterprise, and quantifying assumed changes. The results are useful guideline for taking organizational measures in order to increase economic success of the enterprise. This implies elimination of negative, and emphasis of positive impact of objective and organization-caused factors for making higher economic success. Based on empirical research, it could be concluded that the proposed quantitative models of analyzing the dynamics of enterprise business quality could be applied in practice.
\end{abstract}

Key words: Revenue, Costs, Profit, Factoring, Enterprise, Economics.

\section{Modeli analize uticaja faktora na formiranje profitne stope}

Abstrakt: Analiza u radu je usmerena na identifikaciju uticaja pojedinog faktora na elemente stope dobiti. Primarni cilj rada je prikaz metodoloških

\footnotetext{
${ }^{1}$ Department of Management, The Faculty of Economics Subotica, University of Novi Sad, Serbia, jakovklara@ef.uns.ac.rs

2 Department of Bussines Informatic and Quantitative Methods, The Faculty of Economics Subotica, University of Novi Sad, Serbia
} 
Jakovčević K., Sedlak O.: Models of Analyzing the Influence of Factors on Profit Rate..

rešenja za sagledavanje pune sadržine stope dobiti u svojstvu determinante kvaliteta ekonomije i konačnog pokazatelja rezultata reprodukcije. Aplikacija modela analize faktora stope dobiti obavljena je u preduzeću Republike Srbije koje se bavi proizvodnjom građevinskog materijala od pečene gline. Cilj ove aplikacije jeste provera dometa u utvrdivanju elemenata i faktora ekonomskog uspeha preduzeća, kao i kvantifikacija pretpostavki njegove promene. Dobijeni rezultati su značajni za menadžment preduzeća radi preduzimanja organizacionih mera u cilju rasta ekonomskog uspeha. To znači otklanjanje negativnog,a potenciranje pozitivnog uticaja objektivnih $i$ organizaciono uslovljenih faktora radi ostvarivanja višeg ekonomskog uspeha. Na osnovu empirijskih istraživanja, došlo se do zaključka da se predloženi kvantitativni modeli analize kvaliteta poslovanja preduzeća mogu primeniti u praksi.

Ključne reči: Prihod, troškovi, dobit, proizvodnja, preduzeće, ekonomija.

\section{Introduction}

Enterprise is established with a specific goal, whose realization requires certain investments of labour and capital. The criteria of success in achieving goals also indicate the economic efficiency (Murillo-Zamorano, L.P., 2004) (Fare, R., Grosskoph, S., Lovell, C.A.K., 1985) of an enterprise or running of reproduction process.

In achieving corporate goals, it is necessary to fulfil the interests of participants who took part in its formation, operation and development:

- Finished products or services provided by the scope and quality, should meet the demands and needs of customers;

- All obligations of the enterprise towards suppliers and the community should be settled on time;

- All obligations towards employees, by their work and contribution to the economic success of the enterprise, should be settled on time;

- Ensure payment of the expected return on invested capital to equity holders.

The economic success of an enterprise is the prerequisite and condition for achieving the goals of all participants in the enterprise reproduction. The condition for achieving economic success is the best control of reproduction flow with applying the basic principle of reproduction, that is: achieve maximum results with least investment. When the basic economic principle (Kozuharov, S., 2011, p. 214) is applied to all factors of production, then best economic efficiency is achieved. Economic success as an enterprise goal is achieved in interaction with realization of microeconomic and macroeconomic goals. 
Jakovčević K., Sedlak O.: Models of Analyzing the Influence of Factors on Profit Rate..

One participant in social reproduction (macroeconomics) is the enterprise, whose importance and role depend on function in the process of social reproduction, based on the division of labour. Enterprise's activity depends on the enterprise and the macroeconomic environment. According to the concept of the social division of labour, the economic contribution of specific enterprises within macroeconomics affects, to some extent, the economic activity of other entities as well as fulfilment of the needs of whole society. A feedback system operates in achieving goals of enterprise, microeconomics and macroeconomics.

There are several important economic goals that are defined in the corporate foundation, which may change over time. Usually, the following basic economic goals of enterprise functioning are as follow (Jakovcevic, K., 2006, p. 8):

- Making the largest profit,

- Raising the largest profit rate,

- Rationale for economic development of enterprise ${ }_{2}$ and

- Owners of enterprise's capital growth.

Clear definition of enterprise's goals is an essential prerequisite for survival and economic success in the market conditions (Roquebert, J.A., Phillips, R.L., Westfall, P.A., 1996). In this sense, enterprise's goal has a guiding, motivating, managing and controlling role (Grozdanovic, D., 2004, p. 12).

\section{Economic Success of Enterprise Stated by Profit Rate}

Economic success $(E u)$ of enterprise is achieved by the realization of basic economic principle of reproduction. In quantitative terms, it is determined as the ratio between results (outputs $-O$ ) and investments (inputs $-I$ ) in the reproduction:

$$
E u=\frac{O}{I} \text {. }
$$

The above expression shows overall economic performance in achieving enterprise goals. Dynamics of reproduction, through the state and change in economy of a specific enterprise, reflects the changes in quality of economy and development of economic efficiency. From the aspect of rationality regarding economic success, the changes are important for the relationship between results and investment in reproduction. To understand the position of enterprise relative to the average of the industry or activity to which it belongs, it is necessary to compare the quality of economy and the results of other enterprises. This comparison gives a more realistic assessment of the 
Jakovčević K., Sedlak O.: Models of Analyzing the Influence of Factors on Profit Rate..

economic success of reproduction of a particular enterprise. The purpose of determining factors that caused the relationship between results and investments is definition of actions aimed at achieving the desired quality of the economy.

The rate of profit (Grabowski, H.G., \& Mueller, D.C., 1978) is the final and complete expression of achieving economic success of the enterprise. As an indicator of economic success, it is in line with the basic economic principal of reproduction: to achieve maximum results with minimum investment. In quantitative terms, it is determined by the relationship between profit $(D o)$ and employed capital $(K)$ regardless of its source (Stickney, C., 1996, p. 102) (Hansen, 1990, p. 820):

$d o^{\prime}=\frac{(Q \times C q)-(U \times C u)}{K}=\frac{C-T}{K}=\frac{D o}{K}$.

$d o^{\prime}$ - achieved profit rate; $Q$ - realized volume of production; $C q-$ selling price per unit of product; $C$ - achieved revenue; $U$ - real expenditures of factors of production; $\mathrm{Cu}$ - buying prices per unit of production factors; $T$ real (total) costs; $K$ - real employed capital; Do - realised profit

Since the growth of profit rate in dynamics enables corporate growth and development (Geroski, P., Machin, S.J., Walters, C.F., 1997) (Grozdanovic, D., 2004, p. 343), it really shows economic success with regard to achieving corporate objectives (Galbrait, J., 1979, p. 105). The economic efficiency of spending of all elements of production (expressed as costs in efficiency and as use of workforce in productivity) affects the level of profit realization. The level of profit rate is directly proportional to profit size and diversely proportional to employed capital size. In market economy, profit rate is the basic criterion of corporate efficiency and effectiveness of projects (Roquebert, J.A., Phillips, R.L., Westfall, P.A., 1996). The quality of the economy reported with profit rate is caused by a change of profit and changes in invested capital. Profit rate is changing under the influence of various factors: social, technological, organizational. By differentiating the impacts of various factors on changes in profit rate, it brings the methodological problem of their analysis. Without solving it, it is impossible to observe changes in the quality of the economy reported with profit rate, and conditioning of these changes. The implementation of profit rate is dependent on the methodological abstractions and quantitative expression of factors that influence profit rate. Profit and invested capital affect the function of profit rate. Profit is a function of revenue and costs. The function of revenue depends on the volume of realization and selling prices. Besides price, consumers' preferences and their personnel incomes affect the function of demand for specific products. The cost function depends on many factors such as buying prices and the expenditures of production elements, technology, etc. Coefficient of engagement and the sum of objectively conditioned costs affect 
Jakovčević K., Sedlak O.: Models of Analyzing the Influence of Factors on Profit Rate..

the function of invested capital. In analyzing every element of profit rate, it is necessary to isolate one element, whereby it is presumed that the other elements do not change.

\section{Profit Rate Factors}

\subsection{The Results Of Reproduction In Profit Rate}

All forms of the economic results of reproduction, the volume of realized production $(Q)$, realized value of product $(C)$ and profit $(D o)$ are included the rate of return. The result of reproduction is profit, which is quantitatively determined as the difference between actual revenue and costs:

$$
D o=(Q \times C q)-(U \times C u)=C-T
$$

$U$ - expenditures of production elements; $\mathrm{Cq}$ - selling prices; $\mathrm{Cu}$ - buying prices of production elements

The profit (Cowling, M., 2004) is a direct function of the volume of production or realization and product prices. Size of the physical product is the result of efficiently spending labour and productivity. The volume of production directly affects the size of revenue, but also the level of costs per unit of product. Costs affect the profit per unit of product by difference between market and cost price. Increase in volume results in increase in profit, and thus in growth of profit rate. Conversely, the volume reduction impacts reduction of profit and profit rate, assuming that the selling prices are constant.

Changes in volume of realization and changes in product prices directly affect the realized value of the products or revenue. Prices of products made in the realization on the market, differ from their values influenced by market relations and due to subjective (organizational) measures in a specific enterprise. Higher sales prices increase revenue with assumption that the volume of realization does not change. Conversely, when sale price is lower, the revenue is lower with assumption that the volume of realization is constant. However, the volume of product demand is influenced by the financial strength of consumers, the price level, prices of substitutes, the number of bidders, the number of consumers and other factors. The influence of sales price on the revenue depends on the elasticity of demand.

Size of profit is determined by achievement of preliminary results of the reproduction $(Q, C)$ and by one form of investment in reproduction or costs. As a form of reproduction results, revenue has its economic function in achieving profit rate through profit. In dynamics, influenced by changes in realization volume and sales prices, revenue and profit suffer changes. 
Jakovčević K., Sedlak O.: Models of Analyzing the Influence of Factors on Profit Rate..

Changes happen under the influence of the volume of demand and the impact of subjective factors that generally lead to a reduction in the volume of realization. In planning the necessary or optimal profit in the future, it is necessary to realize the change rate of profit conditioned by the dynamics of revenue. The previous results can serve as a starting point in planning. The change of profit is conditioned by revenue dynamics arising from the dynamics of volume of realization $\left(K_{D o, C}\right)$ and can be expressed with the following formula (Jakovcevic, K., 2008, pp. 430-432):

$$
\begin{aligned}
& K_{D o, C}=K_{D o, q}+K_{D o, C q} ; \\
& K_{D o, C}=\frac{C_{1}}{D o_{1}} \times K_{C} \quad ; \quad K_{C}=K_{D O, C} \times \frac{D o_{1}}{C_{1}} .
\end{aligned}
$$

Change ratio of profit conditioned by revenue dynamics arising from the dynamics of volume of realization $\left(K_{D o, q}\right)$ is determined by the following formula:

$$
K_{D o, q}=\frac{C_{1}}{D o_{1}} \times K q \quad ; \quad K q=K_{D o, q} \times \frac{D o_{1}}{C_{1}} .
$$

Change ratio of profit conditioned by revenue dynamics arising from the dynamics of selling prices $\left(K_{D o, C q}\right)$, can be determined as the difference between change ratio of profit conditioned by revenue dynamics and change ratio of profit conditioned by revenue dynamics arising from the dynamics of volume of realization:

$$
K_{D o, C q}=K_{D o, C}-K_{D o, q}
$$

In dynamics, the costs as the second element of the profit level change under the influence of:

1. changes in market prices of production elements

2. deviations of buying from market prices of production elements,

3 . increased consumption of the production elements,

4. deviation from best capacity use.

Increase in costs in unchanged revenue leads to reduction in profit. To increase profit, it is necessary to cut costs or relatively lower cost growth in relation to revenue growth. Change ratio of profit conditioned by dynamics of costs $\left(K_{D o, T}\right)$ can be expressed as follows:

$$
K_{D o, T}=\frac{T_{1}}{D o_{1}} \times K_{T}
$$


Jakovčević K., Sedlak O.: Models of Analyzing the Influence of Factors on Profit Rate..

Change ratio of profit $\left(K_{D_{0}}\right)$ under the influence of revenue and costs dynamics is represented by formula:

$$
K_{D o}=K_{D o, C}-K_{D o, T} \text {. }
$$

\subsection{Employed Capital in Profit Rate}

The objective and subjective factors influence the invested capital, which is the second element of the profit rate. Subjective (organizational) factors affect the amount of capital through increased investment. Increased investments result from increased costs and prolonged duration of capital employment. The real amount of employed capital $(K)$ is structured from the following (Kukoleca, S., 1973):

1. objectively conditioned sum of capital $(\mathrm{K})$, and

2. organizationally conditioned sum of capital (K)

2.1. organizationally conditioned sum of capital resulting from organizationally conditioned costs $(\mathrm{kt})$

2.2. organizationally conditioned sum of capital resulting from organizationally conditioned extended duration of the capital employment cycle $(\mathrm{kh})$.

$$
K=\mathrm{K}+\mathrm{K} \quad ; \quad K=\mathrm{K}+\mathrm{kt}+\mathrm{kh} \text {. }
$$

The total invested capital and each component of employed capital may change in dynamics. By including elements that are relevant to the size of profits and invested capital, the enterprise follows their impact on the level of profit rate. In the successive period, the profit rate is expressed by change ratios (Grozdanovic, D., 2004, pp. 431-432)

$K d o^{\prime}=\frac{1 \pm K_{D o}}{1 \pm K_{K}}-1$

Change ratio of profit rate is expressed as the sum of the changes based on real profit and employed capital:

$K d o^{\prime}=K d o^{\prime}{ }_{D o} \mp K d o_{K}^{\prime}$.

$K d o_{D o}^{\prime}$ - change ratio of profit rate conditioned by profit change; $K d o_{K}^{\prime}-$ change ratio of profit rate conditioned by change of employed capital

Change ratio of profit rate conditioned by change of employed capital is determined from the relation:

$$
K d o^{\prime}{ }_{K}=\frac{K_{K}}{1 \pm K_{K}} \text {. }
$$


Jakovčević K., Sedlak O.: Models of Analyzing the Influence of Factors on Profit Rate..

Change ratio of profit rate conditioned by profit change is determined from the relation:

$$
K d o^{\prime}{ }_{D o}=\frac{K_{D o}}{1 \pm K_{K}}
$$

These changes are necessary for monitoring the dynamics of reproduction, due to some differences in the impact of individual elements on the change in profit rate. This means that the relative importance of certain elements in the formation of revenue, costs and employed capital can be changed.

\section{Methodology and Results of Research}

Given particular data of enterprise "XY" which produces building materials made from baked clay, presented economic models for analyzing level and factors of profit rate in 2011 and 2012 will be used. The enterprise has a defined heterogeneous range of products that, based on the standard hours of work, amounted to a conditional (dominant) product. We estimate that results value will not be diminished with these calculations of production volume.

\subsection{Methodology and Results of Analyzing the Impact of Revenue on Profit}

Change ratio of profit $\left(K_{D O}\right)$, as an indicator of relative changes of profit in two comparative periods is heavily influenced by revenue and cost dynamics. Its change is equal to the balanced value of the change ratio of profit conditioned by revenue and cost dynamics. Table 1 provides data of specific analysis.

Table 1. The dynamics and factors of revenue (in thousands of dinars).

\begin{tabular}{|l|c|c|c|c|}
\hline \multirow{2}{*}{ Elements } & \multirow{2}{*}{$\begin{array}{c}\text { Symbol } \\
\text { S }\end{array}$} & \multicolumn{2}{|c|}{ Years } & $\begin{array}{c}\text { Coefficient } \\
((2012 / 2011) \\
-1)\end{array}$ \\
\cline { 3 - 4 } & & 2011 & 2012 & - \\
\hline $\begin{array}{l}\text { 1. Possible production volume } \\
\text { (tons) }\end{array}$ & $\mathrm{Q}$ & 200,000 & 200,000 & -1537 \\
\hline $\begin{array}{l}\text { 2. Actual level of production volume } \\
\text { (tons) }\end{array}$ & $\mathrm{Q}$ & 145,851 & 168,275 & 0.1537 \\
\hline 3. Selling price & $\mathrm{Cq}$ & 13.00 & 13.80 & 0.0615 \\
\hline 4. Possible revenue $(1 \times 3)$ & $\mathrm{C}$ & $2,600,000$ & $2,760,000$ & 0.0615 \\
\hline 5. Actual revenue $(2 \times 3)$ & $\mathrm{C}$ & $1,896,068$ & $2,322,192$ & 0.2247 \\
\hline 6. Actual costs & $T$ & $1,745,145$ & $2,094,515$ & 0.2002 \\
\hline 7. Actual profit & $D o$ & 150,923 & 227,677 & 0.5086 \\
\hline
\end{tabular}

Source: Author 
Jakovčević K., Sedlak O.: Models of Analyzing the Influence of Factors on Profit Rate..

Using the analytical expression (4), change rate of profit conditioned by the dynamics of revenue $\left(K_{D o, C}\right)$ in the current year to the result in the previous year is:

$$
K_{D o, C}=\frac{C_{1}}{D o_{1}} \times K_{C}=\frac{1.896 .068}{150.923} \times 0,2247=2,8229 .
$$

In 2012, increase of revenue of $22.47 \%$ affected the increase in profit of $282.29 \%$.

Using the analytical expression (7), change rate of profit conditioned by the dynamics of costs $\left(K_{D, T}\right)$ in the current year to the investment in the previous year is:

$$
K_{D o, T}=\frac{T_{1}}{D o_{1}} \times K_{T}=\frac{1.745 .145}{150.923} \times 0,2002=2,3149 .
$$

In 2012 , increase of cost by $20.02 \%$ affected the decrease in profit by $231.49 \%$.

$C$ - realised revenue; $D o$ - realised profit; $K_{C}$ - change rate of revenue; $T$ realised costs; $K_{T}$ - change rate of costs

Change ratio of profit in the current year $\left(K_{D O}\right)$, as balanced value of revenue dynamics and the dynamics of cost, using the analytical expression (8), is:

$$
K_{D o}=K_{D o, C}-K_{D o, T}=2.8229-2.3149=0.5080 \text {. }
$$

Profit growth of $50.80 \%$ is determined by the revenue growth of $22.47 \%$ (positive phenomenon) and by the costs increase of 20.02\% (negative phenomenon). Faster revenue growth in comparison to cost growth has contributed to profit growth.

Change of profit in dynamics can be determined as the difference between changes in revenue and changes in the costs by applying predetermined coefficients. Growth of revenue is determined as the ratio between the change ratio of profit conditioned by revenue change and change ratio of profit. Increase of costs is determined as the ratio between the change ratio of profit conditioned by cost change and change ratio of profit (analytical expression 14). In quantitative manner, the increase in profit is equal to the difference between revenue growth and cost growth: 
Jakovčević K., Sedlak O.: Models of Analyzing the Influence of Factors on Profit Rate..

$$
\begin{aligned}
& \Delta D o=\Delta C-\Delta T ; \\
& \Delta C=\frac{K_{D o, C}}{K_{D o}}=\frac{2.8229}{0.5080}=5.5569 \text { units; } \\
& \Delta T=\frac{K_{D o, T}}{K_{D o}}=\frac{2.3149}{0.5080}=4.5569 \text { units; } \\
& \Delta D o=5.5569-4.5569=1 .
\end{aligned}
$$

In the same conditions, increase in profit by one percent implies the increase in revenue by 5.5569 units (positive effect) and increase in costs by 4.5569 units (negative impact). Faster increase in revenue than costs contributed to the profit growth. Revenue growth of 1\% allows growth of profit of $0.18 \%$ $(0.508 / 2,8229)$, due to increased costs for difference of $0.82 \%(1-0.18)$. In the reporting period, an increase of profit of $50.80 \%$ with the rising costs of $20.02 \%$ was achieved by increasing the income of $22.47 \%$ (the use of the analytical expression 4).

Since the change in revenue is caused by changes in volume realization and selling prices, their impact on the level of profit is analyzed using the analytical expression (5) and (6).

(a) Profit conditioned by the dynamics of revenue arising from the changes in volume realization is:

$$
K_{D o, q}=\frac{C}{D o} \times K q=\frac{1,896,068}{150,923} \times 0.1537=1.9310 \text {. }
$$

Increasing the volume of production by $15.37 \%$ contributed to the profit growth of $193.10 \%$. However, a change in production volume causes a change in profit over the cost.

(b) Profit conditioned by the dynamics of revenue arising from the changes in selling prices is:

$$
K_{D o, C q}=K_{D o, C}-K_{D o, q}=2.8229-1.9310=0.8919 \text {. }
$$

Increasing the selling prices by $6.15 \%$ contributed to the profit growth of $89.19 \%$.

Change ratio of profit conditioned by revenue dynamics is structured from the following two components: changes based on the dynamics of realization volume and dynamics of selling prices (analytical expression 4):

$$
K_{D o, C}=K_{D o, q}+K_{D o, C q} ; K_{D o, C}=1.9310+0.8919=2.8229 .
$$


Jakovčević K., Sedlak O.: Models of Analyzing the Influence of Factors on Profit Rate..

Increase in profit caused by the dynamics of revenue is caused by the increasing volume of products by $15.37 \%$ (positive effect) and increasing the sales prices of $6.15 \%$ (positive effect).

Profit caused by the dynamics of revenue is determined by the volume of realization of $68.40 \%$ (1.9310: 2.8229 ), and $31.60 \%$ of the selling price, assuming that the costs do not change. If the selling price in the future cannot be increased, the growth of change ratio of profit based on revenue will be achieved only under the volume of realization. In case, the price of the product cannot be increased, and in order to make the same contribution ratio of revenue to the profit (2.8229), it will be needed to increase growth in the realization from $15.37 \%$ to $22.47 \%$. Lowering of sales prices in the future, if the fall in prices can be compensated with the volume growth of sales, it could be accepted as a solution. This assumes the presence of price elasticity of demand for specific products.

\subsection{Methodology and Results of Analyzing the Impact of Costs on Profit}

The influence of cost change to the dynamics of profit can be analyzed from the point:

1. Consumption $(U)$ and the purchase price of expenditures $(\mathrm{Cu})$

1.1.Consumption of production elements $(M, I, R)$

1.2. Purchase prices of consumed elements $(\mathrm{Cm}, \mathrm{Ci}, \mathrm{Cr})$

2. Elements of production $(T m+T r+T i+T K)$

3. Dynamics of costs $(T \pi+T \rho+T \varphi)$

4. Factors in the process of costs formation

Profit varies in inverse proportion to the change in costs. Cost reduction leads to profit growth, while cost growth leads to profit decline.

(1) Costs are determined as product of expenditures and their purchase prices. On this basis, the change ratio of profit conditioned by dynamics of costs (analytic expression 7) is divided into change ratio of profit conditioned by dynamics of production factors expenditure $\left(K_{D o, U}\right)$ and by purchase prices of production factors $\left(K_{D o, C u}\right)$ (Jakovcevic, 2008, p. 432):

$$
\begin{aligned}
& K_{D o, T}=K_{D o, U}+K_{D o, C u} ; \\
& K_{D o, U}=\frac{T}{D o} \times K u ; K_{D o, C u}=\frac{T}{D o} \times K_{C u} .
\end{aligned}
$$


Jakovčević K., Sedlak O.: Models of Analyzing the Influence of Factors on Profit Rate..

(2) Change ratio of profit caused by costs of production factors is determined by the following formula (Jakovcevic, K., 2008, p. 434):

$$
K_{D o, T}=K_{D o, t m} \pm K_{D o, t r} \pm K_{D o, t i} \pm K_{D o, t \kappa} .
$$

The data for the specific analysis is provided by table 2 .

Table 2. The dynamics and structure of total costs (in thousands of dinars).

\begin{tabular}{|c|c|c|c|c|}
\hline \multirow{2}{*}{ Elements } & \multirow{2}{*}{$\begin{array}{c}\text { Symb } \\
\text { ol }\end{array}$} & \multicolumn{2}{|c|}{ Years } & \multirow{2}{*}{$\begin{array}{c}\text { Coefficient } \\
((2012 / 2011) \\
-1)\end{array}$} \\
\hline & & 2011 & 2012 & \\
\hline 1. Achieved (total) costs & $T$ & $1,745,145$ & $2,094,515$ & 0.2002 \\
\hline 2. Objectively conditioned costs & $T$ & $1,333,485$ & $1,525,983$ & 0.1444 \\
\hline $\begin{array}{l}\text { 3. Organizationally conditioned } \\
\text { costs }\end{array}$ & $\mathrm{t}$ & 411,660 & 568,532 & 0.3811 \\
\hline 4. Variable costs & $T w$ & 846,919 & $1,096,479$ & 0.2947 \\
\hline 5. Fixed costs & $T \varphi$ & 898,226 & 998,036 & 0.1111 \\
\hline 6. Material costs & $T m$ & $1,226,792$ & $1,521,920$ & 0.2406 \\
\hline 7. Costs of labour instruments & $\mathrm{Ti}$ & 68,325 & 76,609 & 0.1212 \\
\hline 8. Labour costs & $T r$ & 299,575 & 348,837 & 0.1644 \\
\hline 9. Costs of capital & $T K$ & 150,453 & 147,149 & -0.02196 \\
\hline
\end{tabular}

Source: Author

Change ratio of profit, conditioned by the material expenditures in the current year according to the investments in material expenditures in previous year, is as follows:

$K_{D o, t m}=\frac{T m}{D o} \times K_{t m}=\frac{1,226,792}{150,923} \times 0.2406=1.9557$.

Change ratio of profit conditioned by dynamics of labour costs in the current year to the investment in labour costs in the previous year, is as follows:

$$
K_{D o, t r}=\frac{T r}{D o} \times K_{t r}=\frac{299,575}{150,923} \times 0.1644=0.3263 \text {. }
$$

Change ratio of profit conditioned by dynamics of costs of labour instruments in the current year to the investment of costs of labour instruments in the previous year is:

$$
K_{D o, t i}=\frac{T i}{D o} \times K_{t i}=\frac{68,325}{150,923} \times 0.1212=0.0549 \text {. }
$$

Change ratio of profit conditioned by dynamics of costs of financing in the current year to the costs of financing in the previous year is: 
Jakovčević K., Sedlak O.: Models of Analyzing the Influence of Factors on Profit Rate..

$$
K_{D o, t \kappa}=\frac{T \kappa}{D o} \times K_{t \kappa}=\frac{150,423}{150,923} \times(-0.0220)=-0.0219 .
$$

Components of change in profit from changes in cost of production elements, using the analytical expression (17) are:

$$
K_{\text {Do, } T}=1.9557+0.3263+0.0549-0.0219=2.3150 \text {. }
$$

In the structure of the total cost, the most powerful influence on the growth of costs in the second period was presented by costs of material $(84.48 \%=$ 1.9557 / 2.3150), and then labour costs (14.10\%) and cost of labour instruments (2.37\%). Only the cost of capital had a positive effect on profit $(0.95 \%)$, given that its participation decreased in total costs. The increase in profit over the cost was strongly influenced by reduction in material costs. Reduction in labour costs is of minor importance.

(3) Change ratio of profit conditioned by dynamics of costs is structured in the following two components: change ratio based on variable costs $\left(K_{D o, T w}\right)$ and change ratio based on fixed costs $\left(K_{D o, T \varphi}\right)$ (Jakovcevic, K., 2008):

$$
K_{D o, T}=K_{D o, t w} \pm K_{D o, t \varphi} .
$$

Change ratio of profit caused by the change of variable costs is:

$$
K_{D o, t w}=\frac{T w}{D o} \times K_{t w}=\frac{846,919}{150,923} \times 0.2947=1.6537 .
$$

Change ratio of profit caused by the change of fixed costs is:

$$
K_{D o, t \varphi}=\frac{T \varphi}{D o} \times K_{t \varphi}=\frac{898,226}{150,923} \times 0.1111=0.6613 .
$$

Components of change in profit from changes in the dynamics of costs, using the analytical formulas (22), are as follow:

$$
K_{D o, T}=1.6537+0.6613=2.3150 .
$$

The intensity of the influence of variable costs on the profit reduction was $71.44 \%$ (1.6537 / 2.3150), and $28.56 \%$ of fixed cost $(0.6613$ / 2.3150). Increse in variable costs was $29.47 \%$, while increase in volume of production was $15.37 \%$. Faster growth of the variable costs of production volume negatively affects profit. However, there was an increase in fixed costs of $11.11 \%$. 
Jakovčević K., Sedlak O.: Models of Analyzing the Influence of Factors on Profit Rate..

(4) Change ratio of profit is caused by the dynamics of objectively and organizationally conditioned factors in the process of formation costs. The factors of forming the actual costs can be in general grouped in objective and organizational or actual costs that are structured from two components:

- Objectively conditioned costs $(T)$, which are determined by natural and technological conditions of production and fair (market) price formation,

- Organizationally conditioned costs (t), which are determined by a deviation from objectified organizational elements of the organizational structure (production with reduced use of capacity, organizationally conditioned increase in consumption of production elements, organizationally conditioned deviation of concrete buying price from average market prices of the means of production) (Kukoleca, S., 1973, pp. 702-704)

Since the total costs are structured of objectively and organizationally conditioned costs, an analysis of their impact on the change of profit is shown below.

(1) Change ratio of profit, which is realized on the basis of objectively conditioned costs, is:

$$
K_{D o, \mathrm{~T}}=\frac{\mathrm{T}_{1}}{D o_{1}} \times \mathrm{K}_{\mathrm{T}}=\frac{1.333 .485}{150.923} \times 0,1444=1,2759 .
$$

(2) Change ratio of profit, which is realized on the basis of organizationally conditioned costs, is:

$$
K_{D o, t}=\frac{t_{1}}{D o_{1}} \times K_{t}=\frac{411.660}{150.923} \times 0,3811=1,0395 .
$$

Components of change in profit based on the factors that caused the total cost:

$$
K_{D o, T}=K_{D o, T} \pm K_{D o, t}=1,2759+1,0395=2,315 \text {. }
$$

The increase in the costs is determined by the influence of objective factors of $44.90 \%$ (1.2759 / 2.315), and organizational factors of 55.10\%. Undertaking organizational measures to reduce organizationally conditioned consumption of resources in the process of reproduction can solve the issue with profit increase. 
Jakovčević K., Sedlak O.: Models of Analyzing the Influence of Factors on Profit Rate..

\subsection{Methodology and Results of Analyzing the Profit Rate}

The analyzed elements of results and investment in sections 3.1-3.2 are included in achieving the rate of profit. In quantitative manners, the economic success expressed by rate of profit is determined by the relationship between real profit and actually employed capital. Data needed for analyzing the level and dynamics of profit rate are presented in the table 3 .

Table 3. The dynamics of rate of profit (in thousands of dinars).

\begin{tabular}{|c|c|c|c|c|}
\hline \multirow{2}{*}{ Elements } & \multirow{2}{*}{ Symbol } & \multicolumn{2}{|c|}{ Years } & \multirow{2}{*}{$\begin{array}{c}\text { Coefficient } \\
\text { ((2012/2011)- } \\
1)\end{array}$} \\
\hline & & 2011 & 2012 & \\
\hline $\begin{array}{l}\text { 1. Realised volume of production } \\
\text { (tons) }\end{array}$ & Q & 145,851 & 168,275 & 0.1537 \\
\hline 2. Selling price & $C q$ & 13.00 & 13.80 & 0.0615 \\
\hline 3. Realised revenue $(1 \times 2)$ & C & $1,896,068$ & $2,322,192$ & 0.2247 \\
\hline 4. Realised (total) costs & $T$ & $1,745,145$ & $2,094,515$ & 0.2002 \\
\hline 5. Realised profit & Do & 150,923 & 227,677 & 0.5086 \\
\hline 6. Real employed capital & $K$ & $2,844,102$ & $3,483,288$ & 0.2247 \\
\hline $\begin{array}{l}\text { 6.1. Objectively conditioned } \\
\text { capital }\end{array}$ & K & $2,432,277$ & $2,914,628$ & 0.1983 \\
\hline $\begin{array}{l}\text { 6.2. Organizationally conditioned } \\
\text { capital }\end{array}$ & $\kappa$ & 411,825 & 568,660 & 0.3808 \\
\hline 7. Realised profit rate & $d o^{\prime}$ & 0.0531 & 0.0654 & 0.2316 \\
\hline
\end{tabular}

Source: Author

The actual profit rate in the second period was influenced by: changes in the profit and changes in employed capital. Below can be found determination of the change ratio of profit and employed capital in the current period compared to the previous period.

1) Change ratio of profit in the second period (2012) is:

$$
K_{\text {Do }}=\frac{D o_{2}-D o_{1}}{D o_{1}}=\frac{227,677-150,923}{150,923}=0.5086 ;
$$

The change ratio of profit (0.5086) was influenced by changes in revenue and costs:

$$
K_{D o}=K_{C} \mp K_{T} \text {. }
$$


Jakovčević K., Sedlak O.: Models of Analyzing the Influence of Factors on Profit Rate..

a) The influence of revenue on the change of profit:

$$
K_{C}=\frac{C_{2}-C_{1}}{D o_{1}}=\frac{\Delta C}{D o_{1}}=\frac{2,322,192-1,896,068}{150,923}=2.8235 \text {. }
$$

b) The influence of costs on the change of profit:

$$
K_{T}=\frac{T_{2}-T_{1}}{D o_{1}}=\frac{\Delta T}{D o_{1}}=\frac{2,094,515-1,745,145}{150,923}=2.3149 \text {. }
$$

The balanced effect of those two elements of profit amounts to: $K_{D o}=2.8235$ $-2.3149=0.5086$.

2) Change ratios of employed capital

a) Change ratio of actually employed sum of capital in the second period is determined by:

$$
K_{K}=\frac{K_{2}-K_{1}}{K_{1}}=\frac{3,483,288-2,844,102}{2,844,102}=0.2247 .
$$

b) Change ratio of objectively conditioned sum of employed capital:

$$
K_{\mathrm{K}}=\frac{\mathrm{K}_{2}-\mathrm{K}_{1}}{K_{1}}=\frac{2 \cdot 914 \cdot 628-2 \cdot 432 \cdot 277}{2 \cdot 844 \cdot 102}=0,1696 \text {. }
$$

c) Change ratio of organizationally conditioned sum of employed capital:

$$
K_{\kappa}=\frac{\kappa_{2}-\kappa_{1}}{K_{1}}=\frac{568.660-411.825}{2.844 .102}=0,0551 \text {. }
$$

Change ratio of actually employed sum of capital is structured by the following two components:

$$
K_{K}=K_{\mathrm{K}} \pm K_{\mathrm{K}}=0.1696+0.0551=0.2247 \text {. }
$$

3) Change ratio of profit rate in the second period is determined by using analytical expression (10):

$$
K d o^{\prime}=\frac{1 \pm K_{D o}}{1 \pm K_{K}}-1=\frac{1+0.5086}{1+0.2247}-1=0.2316 .
$$

To determine the isolated effect of profit changes and the particular influence of the capital changes, the following analytical expressions (13) (12) can be used: 
Jakovčević K., Sedlak O.: Models of Analyzing the Influence of Factors on Profit Rate..

1) Change ratio of actual profit rate caused by profit changes amounts to:

$$
K d o^{\prime}{ }_{D o}=\frac{K_{D o}}{1 \pm K_{K}}=\frac{0.5086}{1+0.2247}=0.4128 \text {. }
$$

2) Change ratio of actual profit rate caused by employed capital changes amounts to:

$$
K d o^{\prime}{ }_{K}=\frac{K_{K}}{1+K_{K}}=\frac{0.2247}{1+0.2247}=0.1835 \text {. }
$$

a) The influence of objectively conditioned capital on the profit rate:

$$
K d o^{\prime}{ }_{\mathrm{K}}=\frac{K_{\mathrm{K}}}{1+K_{K}}=\frac{0,1696}{1+0,2247}=0,1385
$$

b) The influence of organizationally conditioned capital on the profit rate:

$$
K d o^{\prime}{ }_{\kappa}=\frac{K \kappa}{1+K_{K}}=\frac{0,05514}{1+0,2247}=0,045
$$

Change ratio of actual profit rate caused by employed capital changes is structured in the following two components:

$$
K d o^{\prime}{ }_{K}=K d o^{\prime}{ }_{\mathrm{K}} \pm K d o^{\prime}{ }_{\mathrm{K}}=0.1385+0.045=0.1835 \text {. }
$$

Profit rate changes are caused by the change of objectively conditioned capital $75.48 \%$ and organizationally conditioned sum of $24.52 \%$.

The coefficient of real profit rate growth in the second period is equal to the sum of the changes based on actual profit and employed capital (analytical expression 11):

$$
\begin{aligned}
& K d o^{\prime}=K d o_{D o}^{\prime} \mp K d o^{\prime}{ }_{K} ; \\
& K d o^{\prime}=0.4128-0.1835=0.2293 .
\end{aligned}
$$

In 2011 , profits increased by $50.86 \%$ which contributed to the growth of profit rate by $41.28 \%$. However, the growth of employed capital of $22.47 \%$ caused a decrease in profit rate of $18.35 \%$. Higher profit growth (positive impact) compared to the growth of employed capital (negative effect) contributed to the growth of profit rate of $22.93 \%$. 
Jakovčević K., Sedlak O.: Models of Analyzing the Influence of Factors on Profit Rate..

Table 4. The relative importance of elements of profit rate.

\begin{tabular}{|c|c|c|}
\hline Elements & Coefficient & $\begin{array}{c}\text { The relative contribution of } \\
\text { elements to profit rate } \\
\text { change }\end{array}$ \\
\hline 1 & 2 & 3 \\
\hline$K^{\prime} d o^{\prime}{ }_{D o}$ & 0.4128 & 1.8003 \\
\hline$K d o^{\prime}{ }_{K}$ & 0.1835 & 0.8003 \\
\hline$K d o^{\prime}$ & 0.2293 & 1.0000 \\
\hline
\end{tabular}

Source: Author

Column 3 shows the relative importance of the contribution of profit and employed capital to the change of profit rate in 2012. Changes based on the coefficient of profit, and changes based on the coefficient of employed capital are set in relation to the coefficient of changes in profit rate. One percent growth of actual rate of profit was achieved with profit growth of $1.8003 \%$ (positive effect) and with employed capital growth of $0.8003 \%$ (negative impact).

The analysis implies that the planning level and dynamics of profit rate require: exploring a number of elements and their interdependence on objective and organizational factors (Hirschey, M., Wichern, W., 1984), defining the strategy of factors, designing components of profit rate caused by individual factors and establishing a control system in achieving the defined strategy of profit rate.

Knowledge about the effects of elements and factors in the formation of profit rate can predict changes in some elements for achieving the desired (optimal) profit rate (Geroski, P., Machin, S.J., Walters, C.F., 1997).

Being familiar with the intensity of influence of certain elements and factors in the formation of profit rate is also an indicator of the order of taking organizational measures for increasing the rate of profit in the current and future period. Changes of individual elements can be also designed to achieve the desired (optimal) profit rate of enterprises or projects (Geroski, P., Jaquemin, A., 1998).

\section{Conclusions}

Achieving the desired rate of profit is the most common goal of an enterprise. Given that this goal is quantitatively measurable and time-definable, it is also used to check the progress and success of business enterprises. However, besides keeping the track and level of results previously achieved, it is 
Jakovčević K., Sedlak O.: Models of Analyzing the Influence of Factors on Profit Rate..

necessary to exactly specify the factors that influence them. The analysis of the factors affecting the formation rate of profit obtained important information. Such information determines specific management decisions on the use of resources to meet a defined goal. They primarily refer to increased use of resources that is influenced by the organization of reproduction process as well as measures to improve competitiveness and market forces of an enterprise.

The main goal of this paper is a presentation and verification of quantitative models for showing factors of enterprise's economic success reported by profit rate. Factors of revenue, costs and capital dynamics are defined within the main goal. The rate of revenue and cost change determines the change of profit, while the relationship between profit and employed capital determines the profit rate. Understanding the factors and their dynamics is a condition for prompt elimination of causes that in short-term can lead to business disruption.

Presented quantitative models objectively identify the causes of economic success change and reliable model for decision-making. Models provide information needed for the design of required intensity of changes in elements of the profit rate in order to make the desired (planned) profit rate on the level of enterprise or project.

\section{References}

Cowling, M. (2004). The Growth - Profit Nexus. Small Business Economics, 22(1), 19. doi:10.1023/B:SBEJ.0000011568.42714.c9

Fare, R., Grosskoph, S., Lovell, C.A.K. (1985). The measurement of efficiency of production. Boston: Kluwer Academic Publishers.

Galbrait, J. (1979). Ekonomika i drustveni ciljevi (Economics and social objectives). Rijeka: O. Kersovani.

Geroski, P., Jaquemin, A. (1998). The Persistence of Profits: A European Comparison Economic Journal, 98 (391), 375-389.

Geroski, P., Machin, S.J., Walters, C.F. (1997). Corporate Growth and Profitability. The Journal of Industrial Economics, 45 (2), 171-189.

Grabowski, H.G., \& Mueller, D.C. (1978). Industrial Research and Development, Intangible Capital Stocks, and Firm Profit Rates. Bell Journal of Economics, 9(2), 328-343. doi:10.2307/3003585

Grozdanovic, D. (2004). Osnovi ekonomike preduzeca (Foundations of Business Economics). Kragujevac: Faculty of Economics.

Hansen, D. (1990). Management Accounting. Boston: PWS-KENT Publishing Company.

Hirschey, M., Wichern, W. (1984). Accounting and Market-Value Measures of Profitability: Consistency, Determinants and Uses. Journal of Business and Economic Statistics, 2 (4), 375-383. 
Jakovčević K., Sedlak O.: Models of Analyzing the Influence of Factors on Profit Rate..

Jakovcevic, K. (2006). Ekonomika preduzeca - ekonomska efikasnost angazovanja kapitala u reprodukciji (Business Economics - Economic Efficiency and Capital Investment in Reproduction). Subotica: Faculty of Economics.

Jakovcevic, K. (2000). Struktura i vrednovanje kapitala (Structure and Evaluation of Capital). Subotica: Faculty of Economics.

Jakovcevic, K. (2008). Upravljanje troskovima (Cost Management). Subotica: Faculty of Economics.

Kozuharov, S. (2011). Mezzo economics analytical approach as the propulsive part of managerial economics in tourism. UTMS Journal of Economics , 2 (2), 213-219.

Kukoleca, S. (1973). Ekonomika preduzeca I, sveska 2 (Business Economics I, volume 2). Belgrade: Faculty of Organizational Sciences.

Mueller, D. (1990). The Dynamics of Company Profits. Cambridge: Cambridge University Press.

Murillo-Zamorano, L.R. (2004). Economic Efficiency and Frontier Techniques. Journal of Economic Surveys, 18(1), 33-77. doi:10.1111/j.1467-6419.2004.00215.x

Roquebert, J.A., Phillips, R.L., Westfall, P.A. (1996). Market vs. Management: What Drives Profitability? Strategic Management Journal, 17 (8), 653-664.

Stickney, C. (1996). Financial Reporting and statement Analysis (Third edition ed.). Colorado: Harcourt Brace\&Co, USA. 